\title{
PREVALENCE OF BOVINE LEUKEMIA VIRUS IN BLACK AND WHITE COWS WITH THE DIFFERENT LEVEL OF MILK PRODUCTIVE TRAITS
}

\author{
N.A. Zinovieva', E.A. Gladyr', I.V. Vinogradova', M.E. Mikhailova ${ }^{2}$, \\ L.A. Molofeeva ${ }^{3}$, L.K. Ernst $^{1}$ \\ ${ }^{1}$ All-Russia Research and Development Institute for Livestock Husbandry, RAAS, Dubrovitsy settlement 142132, Moscow province, Russia \\ e-mail: $n$ zinovieva@mail.ru \\ ${ }^{2}$ Institute of Genetics and Cytology, NAS of Belarus, Minsk 220072, Belarus \\ e-mail: m.mikhailova@igc.bas-net.by \\ ${ }^{3}$ Moscow State University of Medicine and Dentistry named after A.I. Evdokimov, Moscow 127473, Russia \\ e-mail: lyda19-80@mail.ru
}

Received August 13, 2012

$\mathrm{Sum}$ mary

The association study of BLV status (carrier, non-carrier) with the level of milk productive traits in Black and White cows of different lactation periods was performed. The blood samples were derived from the whole herd including 382 cows of fist lactation period, 253 cows of second lactation period and 197 cows of third lactation period. The presence of provirus form of BLV in blood leuco-cytes was detected by nested PCR using developed system. Based on results of PCR analysis the cows received $B L V^{+}$or $B L V^{-}$status. The increase of the number of cows with $\mathrm{BLV}^{+}$status from 28.5 per cent of fist lactation period cows to 36.1 per cent of third lactation period cows was observed. The significantly higher BLV prevalence $(+9.0 \ldots+21.7$ per cent) in fist lactation period cows with the «mean» (within $X a v e r a g e \pm \sigma)$ and «high» (more than Xaverage $+\sigma$ ) levels of milk productive traits (milk yield, fat content, milk fat and protein yield) comparing to «low» productive cows (less than Xaverage- $\sigma$ ) was observed. The data analysis in aspect of different milk productive traits indicated the higher differences between the groups differed in milk fat yield $(18.3-21.7$ per cent, $p<0.999)$. The tendencies described above in the most of cases were observed in the second and third period lactations' cows. The increase of the level of most milk productive traits (milk yield, fat content, milk fat and protein yield) in cows of different genealogical lines with $\mathrm{BLV}^{+}$status comparing to $\mathrm{BLV}^{-}$status was observed.

Keywords: Keywords: bovine leukemia virus, DNA diagnostics, milk productive traits.

Breeding cattle for high milk production contributes to changes in animals' health (1). Higher output of milk extends the share of available energy utilized in the synthesis of milk, and thereby promotes a negative energy balance that can be restored for the expense of body reserves, which in turn, causes a partial decline of condition. Such metabolic load is peculiar to high yielding cows as specific type of metabolism associated with increased synthesis and secretion of milk; in most cases it results in metabolic stress violation of some energetic processes related to, in particular, reproduction and health (2). Metabolic stress during lactation affects the nature of immune response, which was confirmed by K. Kimura et al. (3) who revealed differences in leukocyte patterns of Holstein cows after mastectomy and normally lactating ones. The changed immune profile of high yielding cows is seen as the cause of their susceptibility to diseases (4-9). For example, milk yield and susceptibility to mastitis are linked by the positive genetic correlation varying from 0,24 to 0,55 (5). K.L. Ingvartsen et al. (9) have detected undesirable genetic correlations between milk yield and the incidence of ketosis $(0,26-0,65)$, ovarian cysts $(0,23-0,42)$, mastitis $(0,15-0,68)$, and lameness $(0,24-0,48)$. Increased milk production is also associated with widespread occurrence of bovine leukemia virus (BLV) in dairy cattle. It was shown that Holstein cows of Canadian breeding - BLV-carriers produce higher milk yield than BLV-negative cows (10). BLV status of cows was found to be correlated with a strong genetic potential for milk yield: in cows with persistent lymphocytitosis $+204 \mathrm{~kg}$, in hematologically normal cows $+136 \mathrm{~kg}$ above the estimates of BLV-negative individuals (11). In a sample group of Black-and-White fresh cows, BLV-carriers exhibited the trend to increased levels of some productivity indices compared to animals not infected by the virus (12).

The purpose of this work was studying the relationship between BLV infestation and milk productivity in a herd of high productive dairy cows with respect to duration of their productive use.

Technique. Investigations were carried out on Holsteinized Black-and-White cows farmed in one herd. Blood samples were obtained from animals with completed lactation: the $1^{\text {st }}$ lactation -382 individuals, $2^{\text {nd }}-253$, and $3^{\text {rd }}-197$ cows. The detection of proviral BLV form in blood lymphocytes was performed by nested PCR using the own developed highly sensitive test system for BLV screening. From results of the screening, individual status of cows was determined as BLV+ (BLV-carriers) or BLV-. Parameters of milk productivity (milk yield for 305 days of lactation, $\mathrm{kg}$; fat and protein content in milk, \%) were determined according to zootechnical recordings, yields of milk fat and protein $(\mathrm{kg})$ were calculated by multiplying the milk yield (kg) by the content of, respectively, milk fat and protein (\%) and dividing that value by 100 . According to the calculated values, the cows were divided into three groups with different productivity: low productive (below the mean minus standard deviation $-<$ Xaverage- $\sigma$ ), medium productive (within standard deviation from the mean - Xaverage $\pm \sigma$ ) and high productive (exceeding the mean by more than a standard deviation $->$ Xaverage $+\sigma)$.

Statistical calculations were performed by standard methods (13) using MS Excel software. 


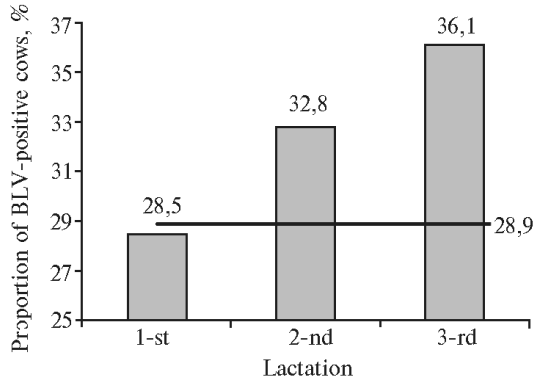

Fig. 1. The proportion of BLV-carriers (bovine leukemia virus) in a herd of Holsteinized Blackand-White cows represented by number of lactation. Horizontal line - the mean proportion of BLV-carriers over the herd
Results. A comparison of BLV infestation (Fig. 1) in groups with different duration of productive use showed the higher proportion of BLV-carriers among the cows that had fulfilled the $2^{\text {nd }}$ and $3^{\text {rd }}$ lactation - by, resp., 4,3 and $7,6 \%$ than in cows of the $1^{\text {st }}$ lactation.

Since BLV status of cows wasn't reliably correlated to their kinship to particular genealogical lines, the analysis of correlations between BLV infestation and productivity was carried out over the total sample group not considering individuals' membership in genealogical lines.

The productivity groups distinguished among cows that had fulfilled the $1^{\text {st }}$ lactation (Table 1) exhibited reliable differences in the analyzed parameters of milk productivity $(\mathrm{p}<0,999)$. In the low productive group, fat content in milk was reliably lower than in the groups of medium- and high-productive cows (resp., $-0,11$ and $-0,12$ abs. $\%, P<0,99)$.

1. Productivity parameters of Holsteinized Black-and-White dairy herd during the $1^{\text {st }}$ lactation, represented by different productivity groups

\begin{tabular}{|c|c|c|c|}
\hline \multirow{2}{*}{ Parameter } & \multicolumn{3}{|c|}{ Productivity group } \\
\hline & $<$ Xaverage $-\sigma$ & Xaverage $\pm \sigma$ & $>$ Xaverage $+\sigma$ \\
\hline Milk yield, $\mathrm{kg}^{\mathrm{a}}$ & $4569 \pm 50^{* * *}$ & $6053 \pm 33 * * *$ & $7731 \pm 68^{* * *}$ \\
\hline Number of animals, $n$ & 59 & 265 & 58 \\
\hline Milk fat content, $\%$ & $3,90 \pm 0,04 *$ & $4,01 \pm 0,03 *$ & $4,02 \pm 0,04 *$ \\
\hline Yield of milk fat, $\mathrm{kg}$ & $178,0 \pm 2,7 * * *$ & $242,5 \pm 2,0 * * *$ & $311,3 \pm 4,9^{* * *}$ \\
\hline Milk protein content, $\%$ & $3,13 \pm 0,02$ & $3,13 \pm 0,01$ & $3,10 \pm 0,02$ \\
\hline Yield of milk protein, $\mathrm{kg}$ & $142,6 \pm 1,7 * * *$ & $189,6 \pm 1,2 * * *$ & $239,7 \pm 2,4 * * *$ \\
\hline Milk fat content, $\%^{\mathrm{a}}$ & $3,45 \pm 0,01 * * *$ & $3,98 \pm 0,01 * * *$ & $4,61 \pm 0,02 * * *$ \\
\hline Number of animals, $n$ & 67 & 253 & 58 \\
\hline Milk fat content, $\%$ & $5918 \pm 97$ & $6130 \pm 69$ & $6004 \pm 116$ \\
\hline Yield of milk fat, $\mathrm{kg}$ & $204,4 \pm 3,5 * * *$ & $244,4 \pm 2,9 * * *$ & $278,2 \pm 5,8 * * *$ \\
\hline Milk protein content, $\%$ & $2,97 \pm 0,01 * * *$ & $3,15 \pm 0,01 * * *$ & $3,21 \pm 0,03 * * *$ \\
\hline Yield of milk protein, $\mathrm{kg}$ & $176,2 \pm 3,0 * * *$ & $192,7 \pm 2,1 * * *$ & $192,7 \pm 3,6 * * *$ \\
\hline Yield of milk fat, $\mathrm{kg}^{\mathrm{a}}$ & $173,1 \pm 1,7 * * *$ & $242,2 \pm 1,7 * * *$ & $318,6 \pm 3,8 * * *$ \\
\hline Number of animals, $n$ & 63 & 258 & 61 \\
\hline Milk fat content, $\%$ & $4709 \pm 62 * * *$ & $6091 \pm 41 * * *$ & $7440 \pm 99 * * *$ \\
\hline Yield of milk fat, $\mathrm{kg}$ & $3,69 \pm 0,03^{* * *}$ & $3,99 \pm 0,02 * * *$ & $4,30 \pm 0,04 * * *$ \\
\hline Milk protein content, $\%$ & $3,06 \pm 0,02$ & $3,15 \pm 0,01$ & $3,12 \pm 0,02$ \\
\hline Yield of milk protein, $\mathrm{kg}$ & $143,8 \pm 1,6^{* * *}$ & $191,4 \pm 1,3 * * *$ & $231,5 \pm 3,3 * * *$ \\
\hline Milk protein content, $\%^{\mathrm{a}}$ & $2,88 \pm 0,01 * * *$ & $3,12 \pm 0,01 * * *$ & $3,42 \pm 0,01 * * *$ \\
\hline Number of animals, $n$ & 60 & 264 & 58 \\
\hline Milk fat content, $\%$ & $6093 \pm 131$ & $6131 \pm 64 *$ & $5824 \pm 116^{*}$ \\
\hline Yield of milk fat, $\mathrm{kg}$ & $3,74 \pm 0,06^{* * *}$ & $3,99 \pm 0,02 * * *$ & $4,30 \pm 0,04 * * *$ \\
\hline Milk protein content, $\%$ & $228,7 \pm 6,6$ & $245,0 \pm 3,0$ & $247,5 \pm 3,6$ \\
\hline Yield of milk protein, $\mathrm{kg}$ & $176,0 \pm 3,8$ & $191,1 \pm 2,0$ & $199,3 \pm 4,0$ \\
\hline Yield of milk protein, $\mathrm{kg}^{\mathrm{a}}$ & $143,1 \pm 1,4 * * *$ & $190,0 \pm 1,0 * * *$ & $241,9 \pm 1,9 * * *$ \\
\hline Number of animals, $n$ & 68 & 253 & 61 \\
\hline Milk fat content, $\%$ & $4694 \pm 57 * * *$ & $6076 \pm 36^{* * *}$ & $7634 \pm 77 * * *$ \\
\hline Yield of milk fat, $\mathrm{kg}$ & $3,82 \pm 0,04 * * *$ & $4,02 \pm 0,02 * * *$ & $4,06 \pm 0,04 * * *$ \\
\hline Milk protein content, \% & $178,8 \pm 2,6 * * *$ & $243,9 \pm 1,9 * * *$ & $310,9 \pm 4,6 * * *$ \\
\hline Yield of milk protein, $\mathrm{kg}$ & $3,06 \pm 0,02 * *, * * *$ & $3,13 \pm 0,01 * *$ & $3,17 \pm 0,02 * * *$ \\
\hline
\end{tabular}

Significant differences in milk yield provided reliable differences in yields of milk fat $(p<0,999)$ and protein $(p<0,999)$. Along with it, groups differing in content of milk fat had reliable differences in the yield of milk fat ( $p<0,999)$. In the group of cows producing low-fat milk, protein content in milk was reliably inferior $(p<0,999)$ to the other two groups, which contributed to lower yield of milk protein $(p<0,999)$ in this group.

Comparing productive parameters in groups of cows with different yield of milk fat $(\mathrm{p}<0,999)$, it was found that the observed differences were caused by both variation in milk yield $(p<0,999)$ and variation in fat content $(p<0,999)$. The reliable intergroup differences in milk yield against the insignificant variation in protein content resulted in reliable differences in the yield of milk protein $(\mathrm{p}<0,999)$.

Groups with different content of protein $(p<0,999)$ also showed reliable differences in fat content $(p<0,999)$. Such differences while the insignificant intergroup variation in milk yield contributed to reliable differences in the yield of milk fat and protein; the groups with increased yield of milk protein $(p<0,999)$ exhibited higher yield of milk fat $(p<0,95)$. Differences in the yield of milk protein $(p<0,999)$ were largely associated with differences in milk yield $(p<0,999)$. Variation in milk yield along with reliably lower fat content in milk of cows producing low yield of milk protein provided reliable intergroup differences in yield of milk fat $(\mathrm{p}<0,999)$. The similar patterns were revealed by comparison of groups with high, medium and low productivity that had fulfilled the $2^{\text {nd }}$ and $3^{\text {rd }}$ lactation (data not shown).

2. The incidence of BLV-carriers (\%) in Holsteinized Black-and-White dairy herd during the $1^{\text {st }}$ lactation, represented by different productivity groups

\begin{tabular}{|c|c|c|c|c|c|}
\hline \multirow{2}{*}{ Parameter } & \multirow{2}{*}{$X_{\text {cp. }}$} & \multirow{2}{*}{ y $\sigma$} & \multicolumn{3}{|c|}{ Productivity group, $\%$} \\
\hline & & & $<X$ average $-\sigma$ & Xaverage $\pm \sigma$ & $>$ Xaverage $+\sigma$ \\
\hline Milk yield, kg & 6079 & 1019 & $16,9 \pm 4,9 * * * *$ & $29,4 \pm 2,8^{*}$ & $36,2 \pm 6,3^{* *}$ \\
\hline Milk fat content, $\%$ & 3,99 & 0,39 & $19,4 \pm 4,8^{*}$ & $30,4 \pm 2,9 *$ & $30,6 \pm 5,9$ \\
\hline Yield of milk fat, $\mathrm{kg}$ & 243,0 & 48,8 & $12,7 \pm 4,2 * * *, * * * *$ & $31,0 \pm 2,9 * * * *$ & $34,4 \pm 6,1 * * *$ \\
\hline Milk protein content, $\%$ & 3,13 & 0,18 & $21,7 \pm 5,3$ & $30,7 \pm 2,8$ & $25,9 \pm 5,8$ \\
\hline Yield of milk protein, $\mathrm{kg}$ & 189,9 & 32,3 & $17,6 \pm 4,6^{*, * *}$ & $30,3 \pm 2,9 * *$ & $32,8 \pm 6,0 *$ \\
\hline
\end{tabular}

In the $1^{\text {st }}$ lactation, in groups with different milk yield (Table 2), the incidence of BLV-carriers was reliably higher among medium- and high-productive cows (by 9,0-21,7\%) than in low-productive animals. In respect to individual parameters, the highest differences were observed between groups with different yield of milk fat: in the low-yielding group, the number of BLV-positive 
cows was $18,3 \%$ lower $(\mathrm{p}<0,999)$ than the mean, and it was $21,7 \%$ lower $(\mathrm{p}<0,999)$ than in the high-yielding group. For protein content, no reliable intergroup differences in BLV incidence was observed. At the same time, for the yield of milk protein, the incidence of BLV carriers in the low-yielding group was $12,7 \%(p<0,98)$ and $15,2 \%(p<0,95)$ less than in, respectively, mediumand high-yielding groups. Apparently, the yield of milk fat is such trait whose manifestation reflects metabolic load to the greatest extent, and therefore, it indicates the amount of metabolic load as well as the level of metabolic stress.

The observed patterns in most cases persisted in cows of the $2^{\text {nd }}$ and $3^{\text {rd }}$ lactations (Fig. 2).

Thus, in the group with high milk yield, the incidence of BLV-carriers exceeded the mean for corresponding lactations, and it was below the mean in groups with low and medium milk (Fig. 2). At the same time, for fat content and the yield of milk fat, there was a different pattern of correlations to BLV infestation: among low-productive animals there was lower BLV incidence, while among medium- and high-productive ones the proportion of BLV-carriers exceeded the mean over the total sample of the relevant lactation. The least pronounced differences in BLV incidence were found in groups differing in content of milk protein. Using the yield of milk protein as a criterion has not allowed to reveal any clear correlations between this parameter and BLV incidence in different lactation cycles. In cows of the $1^{\text {st }}$ and $2^{\text {nd }}$ lactations, the growth in yield of milk protein was accompanied by the trend of increasing BLV infestation, which though wasn't peculiar to the $3^{\text {rd }}$ lactation. The above data suggest that metabolic stress is largely determined by enhanced synthesis of milk fat. Increasing the number of lactations smoothes any differences in BLV incidence, probably, due to exceeding the mean value of productivity indices and a subsequent increase in proportion of cows with metabolic stress (including a group with low productivity).

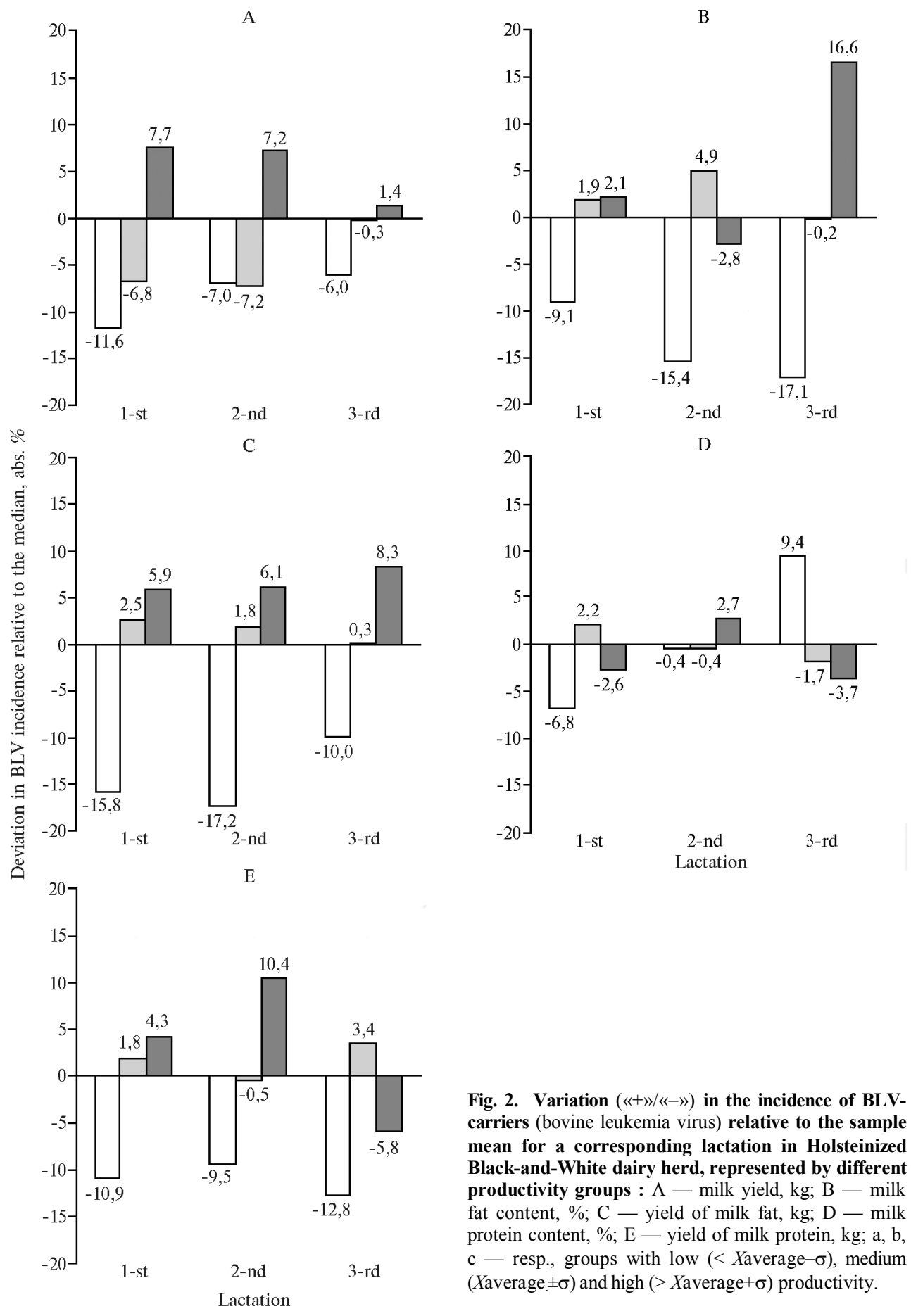

Knowing the role of genealogy for milk productivity of dairy cows, the authors investigated productivity indices of three genealogical lines represented by maximum number of cattle with various incidence of BLV infestation - Wis Back Ideal (WBI, $n=175$ ), Montwick Chieftain (MCh, $n=76$ ), and Reflection Soverng (RS, $n=110$ ) (Table 3). 
3. Productivity parameters of Holsteinized Black-and-White cows of various genealogical lines during the $1^{\text {st }}$ lactation, with respect to their BLV-status (bovine leukemia virus)

\begin{tabular}{|c|c|c|c|c|c|}
\hline \multirow{2}{*}{ Parameter } & \multirow{2}{*}{$\begin{array}{l}\text { Genealogical } \\
\text { line }\end{array}$} & \multicolumn{2}{|c|}{ BLV-positive } & \multicolumn{2}{|c|}{ BLV-negative } \\
\hline & & $n$ & $X$ average $\pm M_{x}$ & $n$ & Xaverage $\pm M_{x}$ \\
\hline \multirow[t]{3}{*}{ Milk yield, kg } & WBI & 50 & $6233 \pm 125$ & 125 & $6008 \pm 90$ \\
\hline & $\mathrm{MCh}$, & 24 & $6074 \pm 158$ & 52 & $5774 \pm 140$ \\
\hline & RS & 29 & $6506 \pm 219$ & 81 & $6066 \pm 120$ \\
\hline \multirow[t]{3}{*}{ Milk fat content, $\%$} & WBI & 50 & $4,05 \pm 0,06$ & 125 & $3,93 \pm 0,04$ \\
\hline & MCh, & 24 & $4,11 \pm 0,07 * * *$ & 52 & $3,88 \pm 0,04 * * *$ \\
\hline & $\mathrm{RS}$ & 29 & $4,00 \pm 0,08$ & 81 & $4,09 \pm 0,04$ \\
\hline \multirow[t]{3}{*}{ Yield of milk fat, $\mathrm{kg}$} & WBI & 50 & $251,9 \pm 5,7^{*}$ & 125 & $237,1 \pm 4,6^{*}$ \\
\hline & $\mathrm{MCh}$, & 24 & $250,0 \pm 8,2 * *$ & 52 & $224,2 \pm 6,1 * *$ \\
\hline & RS & 29 & $261,2 \pm 11,5$ & 81 & $248,2 \pm 5,3$ \\
\hline \multirow[t]{3}{*}{ Milk protein content, $\%$} & WBI & 50 & $3,15 \pm 0,02$ & 125 & $3,11 \pm 0,02$ \\
\hline & $\mathrm{MCh}$, & 24 & $3,12 \pm 0,03$ & 52 & $3,12 \pm 0,02$ \\
\hline & RS & 29 & $3,08 \pm 0,03$ & 81 & $3,17 \pm 0,02$ \\
\hline \multirow[t]{3}{*}{ Yield of milk protein, $\mathrm{kg}$} & WBI & 50 & $195,6 \pm 3,7$ & 125 & $186,8 \pm 2,9$ \\
\hline & $\mathrm{MCh}$, & 24 & $189,0 \pm 4,8$ & 52 & $179,7 \pm 4,4$ \\
\hline & RS & 29 & $200,0 \pm 6,8$ & 81 & $192,3 \pm 3,9$ \\
\hline
\end{tabular}

As it can be seen from Table 3, cows of the $1^{\text {st }}$ lactation - BLV carriers showed a trend to growth in most of the productivity indices (milk yield, fat content in milk, the yield of milk fat and protein). The most pronounced differences were observed in the yield of milk fat (reliable in two of the three lines), which repeatedly confirms the prior informativeness of this parameter in evaluation of the severity of metabolic stress caused by lactation. The similar trends were revealed in cows of the $2^{\text {nd }}$ and $3^{\text {rd }}$ lactation.

Thus, the data of this research clearly demonstrate correlations between BLV (bovine leukemia virus) status of dairy cows and milk productivity during the $1^{\text {st }}-3^{\text {rd }}$ lactation: the growth of milk yield, fat content and yield of milk fat are accompanied by the increase in BLV incidence, which is possibly associated with changes in the animals' immunity during metabolic stress of lactation.

\section{REFERENCES}

1. Oltenacu P.A. and Broom D.M., The Impact of Genetic Selection for Increased Milk Yield on the Welfare of Dairy Cows, Animal Welfare, 2010, vol. 19(S), pp. $39-49$.

2. Clarkson M.J., Downham D.Y., Faull W.B., and Hughes J.W., Incidence and Prevalence of Lameness in Dairy Cattle, Vet. Rec., 1996, vol. 138, no. 23, pp. 563567.

3. Kimura K., Goff J.P., Kehrli M.E., Harp J.A., and Nonnecke B.J., Effects of Mastectomy on Composition of Peripheral Blood Mononuclear Cell Populations in Periparturient Dairy Cows, J. Dairy Sci., 2002, vol. 85, no. 6, pp. 1437-1444.

4. Van Dorp T.E., Dekkers J.C.M., Martin S.W., and Noordhuizen J.P.T.M., Genetic Parameters of Health Disorders, and Relationships with 305-Day Milk Yield and Conformation Traits of Registered Holstein Cows, J. Dairy Sci., 1998, vol. 81, no. 8, pp. 2264-2270.

5. Heringstad B., Klemetsdal G., and Ruane J., Selection for Mastitis Resistance in Dairy Cattle: a Review with Focus on the Situation in the Nordic Countries, Livest. Prod. Sci., 2000, vol. 64, pp. 95-106.

6. Heringstad B., Klemetsdal G., and Steine T., Selection Responses for Disease Resistance in Two Selection Experiments with Norwegian Red Cows, J. Dairy Sci., 2007, vol. 90 , no. 5 , pp. 2419-2426.

7. Kalashnikov V.V., Korovushkin A.A., and Nefedova S.A., Comparative Estimation of Cytomorphological Changes of Lymphocytes in Cattle and AnimalsBioindicators on Territories Polluted with ${ }^{137}$ Cs, S.-kh. biol., 2011, vol. 4, pp. 82-89.

8. Kalashnikov V.V., Korovushkin A.A., Nefedova S.A., and Shashurina E.A., Cytomorphological Monitoring of Dairy Cattle Adaptation to Ecotoxic Pollution in Connection with the Accident at the Chernobyl Nuclear Power Plant, S.-kh. biol., 2011, vol. 6, pp. 19-26.

9. Ingvartsen K.L., On the Relationship between Lactational Performance and Health: Is It Yield or Metabolic Imbalance that Cause Production Diseases in Dairy Cattle? A Position Paper, Livestock Prod. Sci., 2003, vol. 83, no. 2-3, pp. 277-308.

10. Pollary F.L., Wangsuphachart V.L., DiGiacomo R.F., and Evermann J.F., Effects of Bovine Leukemia Virus Infection on Production and Reproduction in Dairy Cattle, Can. J. Vet. Res., 1992, vol. 56, no. 4, pp. 289-295.

11. Wu M.C., Shanks R.D., and Lewin H.A., Milk and Fat Production in Dairy Cattle Influenced by Advanced Subclinical Bovine Leukemia Virus Infection, PNAS USA, 1989, vol. 86, no. 3, pp. 993-996.

12. Gladyr E.A., Zinovyeva N.A., Bykova A.S., Vinogradova I.V., and Ernst L.K., Milk Productivity of Cows in Dependence of the Infection by BVL and Genotype on BoLA-DRB3, Dostizheniya nauki i tekhniki APK, 2012, vol. 8, pp. 46-49.

13. Merkuryeva E.K., Biometriya v selektsii i genetike sel'skokhozyaystvennykh zhivotnykh (Biometrics in Selection and Genetics of Agricultural Animals), Moscow, 1979. 